\title{
The influence of public dispute on trade/investment disputes: Case of SsangYong Motors
}

\author{
Jong-Ho Kim \\ Department of Public Administration \\ Kyung Hee University, Hoegi-dong, Dongdaemun-gu, Seoul, Korea
}

\begin{abstract}
This study explores the important causal relationship between the public (domestic) and trade (international) disputes of South Korea and China. To understand the relations between the domestic and international disputes, Putnam's study of the two-level game theory has been conducted in order to analyze the effect of complicated social and political frameworks on international trade disputes. Due to the social and political differences between South Korea and China, this study provides three findings based on negotiation, policy, and strategic approaches.
\end{abstract}

Keywords: Public dispute, International dispute, Conflict Management and Resolution

\section{INTRODUCTION}

Conflicts and disputes in both domestic and international trade cases in East Asian countries have risen repeatedly. In general, all countries are focusing on enormous efforts to minimize the costs of conflicts because disputes generate national social costs. Governments aim to minimize costs and maximize benefits when they confront any kinds of international and domestic conflict. Moreover, with the wave of neo-liberalism, borderless exchange and changes in globalization and localization, various disputes have been taken as unavoidable when different social and economic systems collide.

According to previous research on various conflicts and disputes, most studies have distinguished public and trade disputes in terms of the characteristics between disputes coupled with national economic interest (anti-dumping, safeguards, customs duties and non-tariff barriers, import restrictions, etc.) and disputes coupled with public interest in society (labor, environment, ideology, region, etc.). Acharya [1] presented that the Asian-Pacific way differed from the American and European way in terms of international conflicts. However, it is not based on a rationalized view, but rather in historical institutionalized characteristics and unique negotiating process in order to solve conflicts between Asian countries. Also, the Asian-Pacific way couldn't provide detailed structures of each country's internal stakeholders and participants. However, recent disputes have evolved into

\footnotetext{
* Corresponding author, Email: jongkim@khu.ac.kr Manuscript received Feb. 13, 2012; revised Apr 25, 2012; accepted Apr 27, 2012
}

complex forms which existing research approaches can't explain as examplified in the cases of the Free Trade Agreement (FTA) with the U.S, the Korea-U.S. beef dispute due to the Mad Cow scare, the Korea-China BOE HYDIS company (LCD) dispute, and the Korea-China disputes on garlic. The demand for new research approaches is growing rapidly. A fitting example can be seen in the ISD (Investor State Dispute) issue over the Korea-US FTA. The ISD issues determine who has the governmental institutional right to issue lawsuits against investors, which can either be interpreted as a public dispute under the territorial principle or as a trade dispute under the nationality principle.

In order to adjust a more appropriate research methodology for the means of analyzing rapidly growing complex social issues as mentioned above, this paper stresses the differences and similarities between the two concepts by defining public dispute and trade dispute. A public dispute is a conflict among various participants with different interests in the domestic decision or policy-making process. By contrast, trade disputes are inter-state conflicts among two or more countries with different interests in international trade and commerce.

Among a myriad of dispute cases, the SsangYong Motors Company (SYMC) case was selected for two reasons. The dispute between South Korea and China occurred because of the vast difference between the two political systems, and the dispute had an enormous impact both internationally and domestically. Because previous studies have not been conducted on this case, this paper sets two hypotheses concerning the interpretation of public and trade disputes. The first hypothesis is that this paper deals with public disputes containing international characteristics because the types of public disputes are extremely diverse and do not 
always directly relate to the behavior exhibited in trade disputes. This paper deals with relations between labor unions and SYMC with a major shareholder of Chinese Shanghai Automobile Industry Corporation (SAIC), which I refer to as a public dispute. The second hypothesis is that the trade disputes are limited to cases of diplomatic negotiation or direct intervention due to a number of disputed trade issues in this paper. For example, this paper deals with the trade dispute caused by the diplomatic negotiation on technology leakage issues between the Korean and Chinese governments.

\section{LITERATURE REVIEW}

There has not been any research published academically on direct relations between public and trade disputes. The research could be more efficient on various disputes due to the diversity and complexity of the scope and scale of these disputes, when considering dichotomous approaches between public and trade disputes. Moreover, it is less academically subject to analysis and practically understandable when researchers are unable to combine two disputes because of growing social complex issues presented above. To link two distinctive types of dispute into one research area, this paper brings along previous researches from political science and economic perspectives. From the perspectives of political science, Walton and Mckersie [21], Rosenau [5], Keohane [19] and other scholars have aimed at clarifying the existence of causal relations between domestic and international politics, and also changing the traditional dichotomous perspective to a more integrated perspective for problem solving.

In terms of economic perspectives, Evans has tried to study international economic effects and influences on domestic economic policies [2]. Other perspective came from Lake and Ikenberry's research [4]. Their research insists that executive bureaucrats in the administrative branch have roles in repackaging domestic problems such as diplomatic issues. In the same context, Spanier and Eric [20] suggest that economic issues are connected with citizens' everyday lives, and domestic economic recessions and increasing unemployment rates may lead to domestic political issues coming to international prominence. Therefore, they claim that economic and diplomatic policies are the "inter-mestic" area where domestic and international policies are closely related to each other. On the basis of these previous studies, Putnam [18], Mayer [15], and Lehman and McCoy [14] have developed research on the interactions of negotiation. In his work, "Side-Payments versus Security Cards: Domestic Bargaining Tactics in International Economic Negotiations," Fridman [3] suggested that bargaining tactics with sidepayments and the redefinition of the case can make domestic support and international economic negotiation much easier than it was previously.

Putnam's [18] theory of the two-level game has a profound impact on studies of international issues such as politics, negotiations, and economic issues. From the perspective of negotiation politics, Putnam [18] explained the interaction of domestic politics and international politics as the answer to policy making and consensus building through the two-level game theory. He criticizes the existing methods of analyzing these two fields separately for the purpose of research convenience and theorizes them by successfully relating the two fields of domestic and international politics. Therefore, Putnam concludes that the two-level game theory of the international negotiation is rooted in domestic political theory. Under this concept of domestic and international politics as the analysis of causal communication, he points out a general theoretical approach which analyzes the interactive relations through the two-level game theory. This theory highlights the important role of domestic political and social framework in order to have successful results in terms of countries' international politics. The homogenous domestic politics comes from the roles of chief negotiators who can positively combine the diverse interest groups and stakeholders. These existing studies provide the theoretical background of relations between public and trade disputes and also help us understand both types of disputes. Unlike other previous research, this paper basically adopts Putnam's [18] theory of the two-level game.

\section{THRE PERSPECTIVES ON THE RELATIONS BETWEEN PUBLIC AND TRADE DISPUTES}

This paper approaches the research on the relations between public and trade disputes from three perspectives: negotiation, the science of policy, and the strategic perspective. The purpose of these different approaches is to seek the relations between public and trade disputes from various viewpoints. However, this paper is a descriptive study with practical schemes because there have not been enough cases on public and trade disputes to verify them statistically.

\subsection{Negotiation perspective}

\subsubsection{Relationship between negotiation and disputes}

Even though disputes do not always lead to negotiations immediately, the intermediating view points of dispute and negotiation have played important roles in defining the similarities of public and trade disputes. This is possible because sequential steps to resolve the disputes and conflicts always exist.

Public dispute as an interaction process of more than two acting subjects with conflicting interests has widely influenced the public. The negotiation of public disputes is resolved by the negotiation, adjustment, administrative execution, and local referendum through a series of interest relations: among private-public, public-public and privateprivate. Public disputes are usually more complex in the conflict resolution process, taking more time for the conflict resolution and achieving consensus through internal negotiation is more difficult [6]. These features have given rise to domestic political and social conflicts, and can lead to economic loss as well as ideological conflicts. Therefore, public disputes are worth studying because of the severity and persistence of conflicts and domestic negotiation, which 
highlights the importance of consensus through internal negotiations.

On the other hand, the definition of trade disputes highlights the disclosure of contradictions derived from various international trades and the conflicting style of international transactions. In these trade disputes, economic gains and losses are results of the industry and the deepening of conflicts. Most trade disputes have been settled through the WTO's Dispute Settlement Organization or the dispute settlement committees of specific agreements. Once the dispute occurs, it leads to international confrontation. To work out this confrontation, trade negotiation is

the best measure to choose. Although trade negotiation occurs at the cooperation stage, this study only discusses negotiation that occurs in the disputing stage. Therefore, trade negotiation can be defined as the table for compromising over economic interests and resolving conflicts between countries.

According many scholars, international negotiation is the issue which ultimately determines the relationship between two or more countries. Therefore trade negotiation is a very important international tool since it is the negotiations reflect the power of economic logic. Since features of trade negotiations should consider the problem of relative gains with other countries in different legal and administrative systems, trade negotiations may occur over the issue of how to distribute economic profit to countries concerned or the damage each economy takes. In terms of scope, subject, and opponent party, public disputes are clearly differentiated from trade disputes.

This study discusses the direct relations between public and trade disputes from the view point of Putnam's two-level game, which effectively utilizes the current research on negotiation. The basic assumptions of a two-level game are that the international and domestic negotiations will be formed simultaneously. While the countries are negotiating the disputes, it is assumed that each government is negotiating the same issues with domestic groups at the same time. In such a situation, the two-level game theory concludes that the country with more discretionary power supported by the domestic concerned groups has an advantage over other countries in international negotiations. Even though this viewpoint of the two-level game seems to only explain the negotiation process for win-set situations, it becomes easy to discuss public and trade disputes by reconstructing the dispute's origin. That is, the failure of mutual consent in domestic negotiations may lead directly to creating and spreading public disputes in their countries. The breakdown of international negotiations such as trade negotiation may be assumed to become a source of trade disputes.

Based on this logic, ruptures of both international trade and domestic negotiations can cause high chance of both trade and public disputes: 1) Rupture of international trade negotiations $=$ high chance of trade dispute and 2) Rupture of domestic negotiation $=$ high chance of public dispute. The logic of a two-level game in terms of international trade and domestic negotiations considers the international negotiation process as a game stage where the bargaining phase of level 1 and the ratification phase of level 2 proceed at the same time. Win-set defines the size of a set of concurrences in level 1 for securing the plurality for ratification in level 2 . Therefore, the public and trade can share the common negative result from the failure of internal and external negotiations. <Figure 1> schematizes both types of public and trade disputes. Although $<$ Figure $1>$ defines the commercial conflict as the conflict and dispute between two companies in different countries, the category of trade disputes includes this commercial conflict in this study.

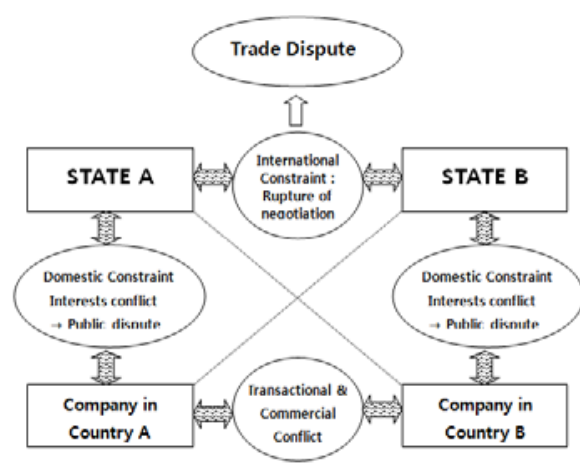

Fig.1. Relation scheme: two types of disputes ${ }^{1}$

3.1.2 SsangYong Motors: trade and public disputes

As shown in <Table 1>, the SYMC trade dispute dates from October 2004, when the sale negotiation began, to January 2009, when the court receivership due to Chapter 11 began negotiations. Since the conflicts and benefits are determined by the result of the negotiations as two countries are the main negotiator, SYMC's creditor's group representing the Korean government, and SAIC owned by the Chinese government. During that period, the actual dispute of SAIC had been severely disclosed in SYMC's technology leak (National Core Technology: Hybrid and automotive design), restructuring, and no fulfillment of investment. At the same time, it is evaluated as a negotiation failure in terms of negotiation theory because of its opposition to Korea's political, economic, and social environments.

Table. 1. Stage of Disputes: SsangYong Motors

\begin{tabular}{cc}
\hline TIME & TYPES OF DISPUTES \\
\hline October, 2004 January, 2009 & Trade dispute \\
January, 2009 $\sim$ August, 2009 & Public dispute included) \\
& \\
\hline
\end{tabular}

After court receivership due to Chapter 11 in January, 2009, SAIC as a major shareholder of SYMC had shifted all responsibility for the dispute on SsangYong's management and had confronted the labor union. This confrontation had consistently resulted in rupture of negotiations between labor and management, which had deteriorated into ideological demonstrations and labor struggles. SAIC finally escalated this confrontation into a severe public dispute through serial

\footnotetext{
${ }^{1}$ Source: modified from Putnam[18] and Moravcsik [17]
} 
bankruptcies, social threats, and a crisis of unemployment.

\subsubsection{Relation between public and trade disputes}

First, while the negotiating subject of trade disputes is the country, the company usually has a direct interest. In other words, trade disputes expand depending on how public disputes by influence internal conflicts between business corporations. Companies are also the direct recipients of the benefits of their country's negotiation and negotiating power. Even though the Korean government had secured the evidence of SAIC's technology leak, it could not handle legal settlement at that time. As a result, the dispute on the SYMC has been confronted by a catastrophic settlement.

Secondly, deepening public disputes usually make the establishment of a win-set case difficult, which leads to weakening of external bargaining power. Through the bargaining process, negotiators have limits upon their discretion dubbed win-sets. A win-set includes every option available to the representatives which could be ratified in their respective states. Since any agreement would be fruitless without ratification, the negotiators must consider domestic factors along with their national interests. As shown in $<$ Figure $2>$, an agreement may be concluded in the range where the win-sets of two states overlap. If a state's win-set is broad it is more likely to conclude an agreement, but may hold relatively weaker bargaining power since the opposite party may have more alternatives which overlap with that state's win-set.

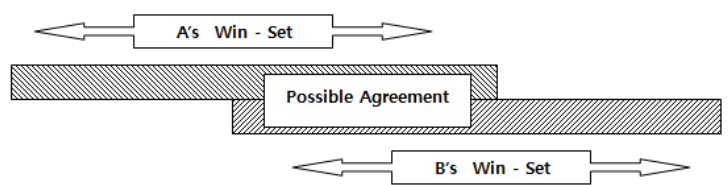

Fig. 2. Possible agreement range by Win-Set

Finally, public disputes may provide the causes of trade disputes. Long-lasting confrontation without negotiation between SAIC and the labor union had spread to the diplomatic conflict between China and Korea.

\subsection{Policy perspective}

Despite ideology and institutional systems, national policies are made through the interaction between government, corporations, and people. While the success of policy outcomes have been rewarded as social and public interests and economic profits, failure can sometimes be expressed by internal and external conflicts and disputes. Within the different conceptual perspectives of capitalism and socialism, there are big differences between management, decision-making and feedback of business corporations, and public administration and government policy-making. In other words, as shown in $<$ Figure $3>$, the integrated corporatism among government, business corporations, and labor characterizes socialist regimes because business corporations as hierarchical units are merely tools of government policy in traditional socialist countries.

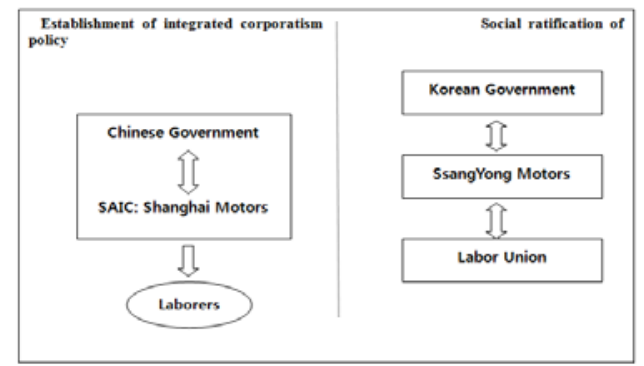

Fig. 3. Relations among Government, Company \& Labor: Socialist vs. Capitalist

Therefore, public disputes in socialist countries are mostly civil cases rather than criminal cases with the government as a direct legal object. Even if a strike occurs as a form of conflict and dispute in socialist countries, private parties such as labor and business corporations are forced to surrender to the impact of government policy in many cases. The Chinese government guarantees the right to organize and the right to bargain collectively among three rights to work. At the same time, the relations among government, business corporations, and labor have communal features with organic cooperation because the right to act collectively is prohibited. However, these communality features have been gradually changing as increasing opportunities to exchange with capitalist countries increase. Similar cases can be seen in acrimonious trade disputes between China and the U.S. about tires, chicken, and cars. Both governments have faced domestic pressure to take a stand on economic issues. As the Obama Administration's first priority on international trade, the US government brought lawsuits to the WTO against raw material exports to China and Chinese chicken exports to the US. To do this, the Obama Administration tried to resolve the global market imbalance and to mollify public ire and labor unions. In contrast, business corporations in capitalist countries have influenced or have been influenced by government policy making. On the other side of government policy, they are interested in seeking values and policy validity in policymaking. There has been perpetual friction among government, business corporations, and labor because the political intentions or errors caused by unrealistic factors can't be verified. Finally, the aspects of disputes change depending on the interpretation of economic logic. Through the SsangYong Motors case, this paper aims to explain that there are many public dispute cases which have been spread into trade disputes and caused external losses due to the negative social effects of public disputes.

\subsubsection{Korean and Chinese policies on $\mathrm{M}$ \& $\mathrm{A}$ of Ssang Yong Motors}

The Chinese government has continuously pursued the introduction of foreign capital and technology policy as the driving force of the socialist market economic system. However, the Chinese government has realized its relative inferiority in the world economy due to increasing foreign dependency and decreasing national competitiveness. Therefore, it has been pursuing a JowooChuChwi (走出去: going to foreign countries) strategy for natural resource 
development and export-oriented policy by preparing an industry list for foreign investments every year. China has had advanced foreign technologies transferred to China's own technologies through aggressive foreign investment. China has deep concerns and high expectations for the automotive industry, and because of the tariff reduction and elimination of the import quota, rapid import increase of cars and parts due to China's opening market may come to a crisis for the Chinese industries. China believes that globalization of the automotive industry can minimize damages and create new added value. Therefore, the Chinese government policy has led to social consent and unprecedented support for very competitive companies in development and production of domestic automobile brands. By providing active support for M\&A and purchasing subsidies, the Chinese government authorized the automobile industry as a national core industry. Recently these efforts have resulted in several deals such as those between SAIC and Saab, and Geely Motors of China and Volvo.

Because of the economic crisis, a by-product of the increasing competitive global automotive market, the Korean government has restructured five domestic automobile industries. As a result, Hyundai, Kia, Daewoo, Samsung successfully merged, excluding SYMC. Therefore, creditors and management of SsangYong hurried to negotiate to merge with SAIC. SsangYong's labor union was strongly opposed to M\&A negotiations with SAIC, despite of chronic financial pressures and limited domestic market. However, SsangYong's creditors and management had come to the decision to sell to SAIC for the following reasons: the merger would move SYMC from the limited domestic market to the huge and expanding Chinese market; SAIC guaranteed employment succession; SAIC proposed a US $\$ 1$ billion investment plan by 2008; and the merger would expand existing facilities and sales networks.

Although the M \& A of SYMC and SAIC served common national interests, the Korean government could not introduce those interests into a reasonable internal agreement between SYMC and its union. In M\&A cases between different nationalities that harbor conflicting ideologies in the business, corporate culture, financial disclosure, technology, a policy strategy to achieve a win-win outcome is essential, but it was lacking in this case. Conflicts between incompatible interests stood in the way; particularly, SAIC pursued a deceptive policy of acquiring SsangYong's technologies while claiming to ask only for financial support. Diplomatic intervention was required because the negotiating parties had been confronted by long-term labor strikes, technology leaks, and broken promises.

\subsubsection{Strategic perspective}

In international negotiations, national-level strategic outcome is defined as the diplomatic and economic outcomes due to a country's strategy. Strategic outcomes on the domestic level can be acquired as a visible and invisible profit through the interests of government, corporations, or individuals. Because strategic action produces distributive gain and loss by mutuality, it is considered very hostile and competitive. Therefore, mutual strategies are usually seen as an important cause of conflict because disputes and conflicts occur depending on how equity is maintained. In modern China, zero-sum game theory has been utilized externally to increase competitiveness of domestic industries. Even though zero-sum game theory tends to be risky in terms of conflict and retaliation, many benefits are guaranteed with superior strategies in the short-run.

As depicted in <Figure $4>$, after undertaking the merger with SYMC, SAIC had command of a 'double play' strategy similar to the zero-sum game strategy. More specifically, for the safe achievement of management goals, SAIC continually forced the transfer advanced technology and aggressive restructuring of SYMC by pleading hardship in fulfilling the financial obligation. The Korean investigation into the technology leak was considered a retaliatory measure in the arena of trading action. China's strategy was to make the Korean government powerless by diplomatic pressure and to force SYMC to surrender with economic pressure. China was successful in blocking Korea's policy flexibility.

First, in the case that economic pressure is higher than the diplomatic pressure (expression 1), the internal conflict is amplified, the government's active intervention is requested as conflict worsens, and the level of government intervention is also increased. In fact, the Korean government actively investigated the first technology leak in the initial stage of SAIC's undertaking. At the same time, it indirectly intervened in SAIC's reimbursement of guaranty for SYMC.

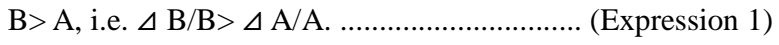

Secondly, in the case that diplomatic pressure is higher than the economic pressure (expression 2), the intervention in the dispute is decreased on the national level. Since the political and economic dependencies in China are relatively high, direct intervention in public disputes may increase the political pressure on the government. Eventually in the case of severe public dispute, the government seeks to minimize clashes and conflicts with other governments with public authority and Internal bargaining power.

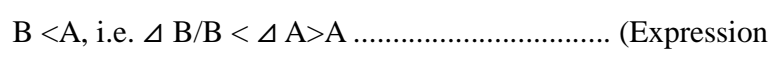

2)

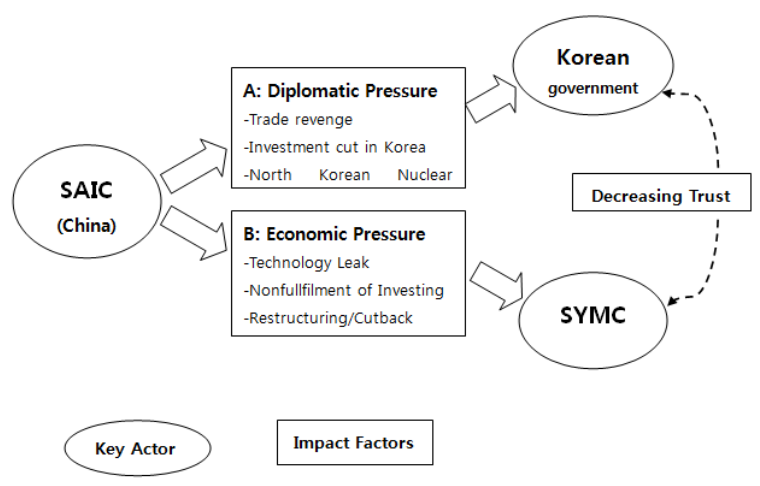

Fig. 4. Double-Play Strategy of the SAIC 
The 'double play' strategy of Chinese SAIC has eliminated Korea's internal defense capacity against economic pressure by lowering trust between the Korean government and SYMC. As a result, the social vulnerability to external impacts depends on Korea's internal ability to respond. Therefore, aggravation of a public dispute became a trade dispute in Korea, where responsive capacity is very weak.

\section{CONCLUSION}

Due to rapid globalization, public and trade disputes have become increasingly diverse and more frequent. Since structures of public and trade disputes have changed from typical structures to specific causal relations, current studies on conflicts and disputes can't explain these newer cases. Therefore, this study concludes by analyzing the relations between the international public and trade disputes.

First, international public and trade disputes are significantly related in terms of negotiation studies. Since negotiation basically implies cooperation and conflict, negative effects resulting from negotiation failure can easily start heated disputes such as public and trade disputes. Because practical advantages of trade negotiation to resolve trade disputes usually accrue to business corporations, results from trade negotiations have a very large impact on their growth. In addition, the continuing conflict due to public disputes has led to weakening of bargaining and negotiating power, since public and trade disputes have a mutual relationship.

Second, one-sided government policy without internal common consent due to the invalidation of efficiency is bound to be disputable. Since the policy does not always directly lead to profit gains, the company and the labor union need to constitute an internal agreement on the value. Consequently the conflict due to the public disputes persists in the absence of policy shifts and become an indirect cause of trade disputes due to the antipathy of the union towards other countries.

Third, strategies for profit expansion against other countries without equality have made the internal and external conflicts worse, and the lack of internal ability to respond to the conflict evolves into a trade dispute. In this particular case, the Chinese could accumulate advanced technology by treating trade as a zero-sum game, and they achieved their practical goal by applying the double-play strategy against the management of SYMC in South Korea.

Judging from the three related factors above, public and trade disputes are significant to further research. Future research in this area will have a touchstone role to solve the various conflicts and disputes. Research on disputes and conflicts should focus on development of understanding various types of disputes such as those involving the tradegovernment-private cluster and government-private conflict. Also, researchers should make continuous efforts in seeking efficient preventive measures and solutions to the rapidly changing dispute types.

\section{REFERENCES}

[1] Acharya, Amitav. 1997. Multilateralism: Is There an Asia-Pacific Way? NBR (National Bureau of Asian Research) Analysis, vol. 8, no. 2, pp. 5-18.

[2] Evans, Peter B. 1979. Dependant Development: The Alliance of Multinational, state, and Local Capital in Brazil. Princeton, N.J.: Princeton University Press.

[3] Fridman, H. Richard, 1993. Side-Payments versus Security Cards: Domestic Bargaining Tactics in International Economic Negotiations. International Organization, vol. 47, no. 4, pp. 387-410.

[4] Ikenberry, G. John. 1988. Reasons of State: Oil Politics and the Capacities of the American Government, Ithaca, N.Y.: Cornell University Press.

[5] Keohane, Robert O. 1985. After Hegemony: Cooperation and Discord in the World Political Economy. Princeton, N.J.: Princeton University Press.

[6] Ka, Sang Jun, Sun Chul Ahn, Lim Jae Hyung and Hak Lin Kim. 2007. Present state of Korean public dispute and characteristics: 1990-2007. Korean Journal of Political Science, vol. 43, no. 2, pp. 56-57.

[7] Kim, Dal Jung. 1998. Understanding of diplomatic policy theories. Seoul, Republic of Korea: O Rum Press.

[8] Kim, Tae Hyun, Suk Jin Yoo and Jin Young Jung. 1998. Diplomacy and politics. Seoul, Republic of Korea: O Rum Press.

[9] Kim, Tae Ki. 2005. Problems and improvement on conflict resolution policies: Focusing on public disputes. Prepared for presentation at Korean Political Science Association Conference.

[10] Kim, Tae Ki. 2007. The empire of the wealth. Seoul, Republic of Korea: Kyung Moon Press.

[11] Lake, David A. 1988. The State and American Trade Strategy in the Pre-hegemonic Era. International Organization, vol. 42, no. 1, pp. 33-58

[12] Lee, Dal Kon. 2005. Negotiation theory, Seoul, Republic of Korea: Bup Mun Press.

[13] Lee, Soo Min, 2009. The Analysis of the Korea-Chile and the Korea-Singapore FTAs : Focusing on the Negotiation through Robert D. Putnam's Win-set. Prepared for delivery at the Annual Meeting of the Midwest Political Science Association, Chicago, April 2009.

[14] Lehman, Howard P. and Jennifer L. McCoy. 1992. The Dynamics of the Two-Level Bargaining Game: the 1988 Brazilian Debt Negotiations. World Politics, vol. 44, no. 4, pp. 600-644.

[15] Mayer, Frederick W. 1992. Managing Domestic Differences in International Negotiations: the Strategic Use of Internal Side Payments. International Organization, vol. 46, no.4, pp. 793-818.

[16] Mo, Jong Lin and Byung Il Choi. 2006. Trade negotiation in Korea, Seoul, Republic of Korea: O Rum Press.

[17] Moravcsik, Andrew. 1993. "Introduction: Integrating International and Theories of International Bargaining." In Double- Edged Diplomacy: International Bargaining and Domestic Politics, edited by Evans, Peter B. 
Harold K. Jacobson and Robert D. Putnam, Berkley CA: University of California Press.

[18] Putnam, Robert D. 1988. Diplomacy and Domestic Politic: the Logic of Two-Level Games, International Organization, vol. 42. no. 3, pp. 427-460.

[19] Rosenau, James N. 1966. "Pre-theories and Theories of Foreign Policy." In Approaches to Comparative and International Politics, edited by R. Barry Farrell, Evanston, Il.: Northwestern University Press.

[20] Spanier, John and Eric. M. Y. Uslaner. 1985. American Foreign Policy Making and the Democratic Dilemmas, New York: Holt, Rinehart and Winston.

[21] Walton, Richard E. and Robert B. Mckersie. 1965. A Behavioral Theory of Labor Negotiations: An Analysis of Social Interaction System, New York: McGraw-Hill.

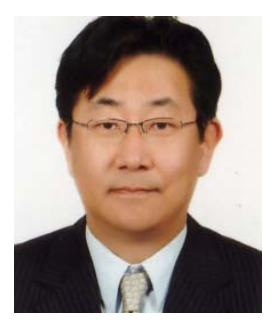

\section{Jong Ho Kim}

He received the B.A. in Sociology from Korea University, Korea in 1985, respectively and also received M.A in sociology from University of Pennsy lvania, USA in 1987. He finally received Ph.D. in Public Policy from Syracuse University, USA in 1993. Since then, he has been with the Public Administration Department, Kyung Hee University, Korea. His main research interests include Public Policy Making and Evaluation, Bureaucratic Politics and Government Innovation. 